\title{
INTRAPRENEURIAL DYNAMICS: A CASE RESEARCH AT THE INSURANCE INDUSTRY IN PORTUGAL
}

\author{
Bruno F. ABRANTES \\ Business Research Unit (BRU), ISCTE University Institute of Lisbon
}

\begin{abstract}
This research focusses on the firm endowments; focusing on the impact of an organizational structure and its managerial systems as the intrapreneurial conditions (IC) for constraining and/or leveraging behavioral patterns of intrapreneurial dynamics (ID). With a positivistic stance and deductive approach to theory development, the researcher attempts to test the phenomenon using a single case design with a holistic frame. The intrapreneurial assessment model of Hartman (2006) outlines the IC variables. Online questionnaires directed to the stakeholders of the partaking firm have originated a probabilistic and randomized sample of 9,70\% of respondents of the targetpopulation (670 employees). We argue that the firm's environment has a direct impact on the intrapreneurial behavior at both, managerial and non-managerial levels, since data exhibits an interaction of variables IC-ID with a positive correlation in its mutation patterns. Herein, is not encompassed the subset of ID with roots upon corporate entrepreneurship (CE); however, it constitutes a clear gap for further statistical and analytical generalizations. This study illuminates the determinism of the organizational ecosystems on the formation of intrapreneurial ideas and ventures and shaping the new intraprises with regard to Entrepreneurial Employee Activity (EEA).
\end{abstract}

\section{KEYWORDS}

Corporate entrepreneurship (CE), entrepreneurial employee activity (EEA), intrapreneurship, intrapreneurial conditions (IC), intrapreneurial dynamics (ID), intraprise

\section{JEL CLASSIFICATION}

L26, L25, L22.

\section{INTRODUCTION}

The ability of the firm to compete is intrinsically attached to its resources ownership (Oviatt and McDougall, 1994; Eisenhardt and Martin, 2000). Yet, several studies support an alternative stance. Unlike valuing resources, they advocate the criticality of the formation of organizational capabilities, rooted on the processes and routinization, are an explanatory factor condition of knowledge acquisition and attainment of innovations in the market (Teece et al., 1997; Eisenhart and Martin, 2000; Weerewardena et al., 2007; Brennan and Garvey, 2009; Cardeal and António, 2012). 
This study focus on the endowments of a firm: structure configuration, resources, processes and culture in order to comprehend how these affect the capability-building mechanisms towards an entrepreneurial culture that empowers intrapreneurs and changes strategic positions and business competitiveness (Wang and Ahmed, 2007). Thus, the study unfolds as follows: first, addresses the theoretical framework on the fields of corporate entrepreneurship and intrapreneurship beginning with seminal conceptualizations, and the contextualization of the investigation. Secondly, introducing the methodological design rooted on a holistic single case design research and revealing the contours of data collection and sampling frame tools, and the underlying data manipulation and analysis. Then, at the final section discusses previous results, findings and delivering its conclusions.

\section{THEORETICAL FRAMEWORK}

Literature in macro, micro, transactional cost and evolutionary economics, and management sciences and business administration, and most particularly the systems theoretical approach has extensively referred to the complexity of company-market interrelations, and the influence of external market factors in company's performance. However, it should not be neglected the firm internal endowments as argued by the resource-based theory (RBT) the so-called resource-based view (RBV) with micro-foundations of the Penrosian growth of the firm. Several authors postulate within the RBT/RBV an entrepreneurial view, which argues the link between innovation and competitiveness, while recognizing the importance of human capital and the employees' proactiveness to achieve the latter. Similarly, Kovács et al. (1998) argue that the lack of innovation strategies and knowledge development may requires a dichotomic approach through two different perspectives. One stricto sensu perspective confined to the technique or technology (technocentrism) in which information and communication technologies are seen as a means of replacing human expertise, through the incorporation of maximum knowledge, regularized and formalized, in computer programs. The second perspective does not confine itself to technological resources but it provides a broader use of all tangibles and intangibles in the organization (anthropocentrism) and suggests the adoption of Anthropocentric Production Systems (APS) with architectures designed to value people, and the qualification of human resources, in clear approach towards the capabilisation the firm. An APS approach acknowledges the principles of decentralized and participatory structures in firms, aiming to generate innovation, not only technological, but also in organizational management, processes, business models, and products and services. Likewise, the innovation process within the organizational environment, named as "intrapreneurship" by Kuratko and Hodgetts (1995:121) is perceived as a synonym for business competitiveness, and therefore a central concern of companies in the XXI century (Lozinsky, 2010). Thus, Brandão (2008:120) claims this construct "in the modern sense ... should not be understood as an external fact to man, but rather as a choice and construction." "The future is intrapreneur" stated Pinchot (1985:321) emphasizing the role of intrapreneurship in innovation's value creation. In addition, Behram \& Özdemirci (2014) recognize corporate entrepreneurship as an important means to ensure the survival and prosperity of companies, while an IBM (2010) report "Capitalizing on Complexity, Insights from the Global Chief Executive Officer Study" corroborates both ideas underlining intrapreneurship as an effective solution for managing complexity in business and innovation's progression.

\subsection{From Conventional Entrepreneurship to Entrepreneurship inside the Organizations}

The study begins with a conceptual approach to the conventional entrepreneurship, and intrapreneurship in the organizations, a task that does not seem easy. Audrestch et al. (2002) assert that part of the difficulty in defining entrepreneurship lies in the multidimensionality feature of the concept that encompasses a variety of fields, being a phenomenon that crosses borders, assuming 
different ways of expression and different amplitudes, according to industrial, cultural, geographical and temporal differences. Also the Global Entrepreneurial Monitor Report reflects, likewise, the complexity of this concept in his own definition: "The entrepreneurship process is a complex endeavor that is affected by many factors, including prevailing attitudes within a society, the rate of activity and the kind of opportunities available, and the growth aspirations of entrepreneurs "(Xavier et al., 2012:18).

Regarding the entrepreneurship within the organizations, it is acknowledged that the first use of the term "intrapreneur" attributed to Gifford Pinchot in 1978 (Baruah and Ward, 2013). Similarly, Miller (1983) considered entrepreneurship inside the organizations as the ability to innovate, to take risks and compete proactively. Later, Pellman and Pinchot (1999) defined intrapreneurial activity (intrapreneuring) as the everyday innovations that make the company more agile to respond to customers taking as a starting point, an idea, a desire to overcome itself, or simply provide a service more cost-effectively. The authors contend that any innovation requires the willingness of an intrapreneurial person to assume the command, and the relentless persistence to make it happen. Other scholars have also addressed the entrepreneurial dynamics topic in the organizations, such as Zahra (1995), Antoncic and Hirsch (2001) and Mintzberg (2007), and conceptualized it as intrapreneurship. Mintzberg (2007) argues that intrapreneurial dynamics is a positively sensitive phenomenon perceived within adhocratic structures where intrapreneurs are risk-takers in order to achieve personal rewards.

Further conceptualizations have emerged from the corporate entrepreneurship, such as "intracapital" as the use of internal risk capital (corporate venture capital) for the establishment of an internal fund, to serve intrapreneurial projects (Kuratko and Hodggets, 1995). The previous concept precedes the notion of "intraprise" (as "an entreprise inside an entreprise") describing it as being the functioning of a business within another business, as a way of explaining what intrapreneurs are creating inside the company they work regardless of whether it is a new product, service, process, or spin-off launch (Pellman and Pinchot, 1999:3). Nevertheless, an alternative conceptual path is suggested by Bosma et al. (2013) similar to the Global Entrepreneurship Monitor Report in which they separate the business entrepreneurship in three different conceptions: (a) corporate entrepreneurship; (b) intrapreneurship; and (c) Entrepreneurial Employee Activity (EEA). For these authors, corporate entrepreneurship (CE) is a top-down process, which has its origin in the diffusion of management efforts and initiatives for business development. The authors relate EEA with employee individual actions, and therefore a bottom-up process in which the individuals develop entrepreneurial initiatives of labor proactiveness. Briefly, intrapreneurship is a joint dynamic of EEA with corporate entrepreneurship. Thereby, the research takes a differentiating stance diverging from the conceptions of linearity, which claim, the corporate entrepreneurship and intrapreneurship egalitarianism, and an epistemological assumption show be raised to clarify the definitions adopted in this study. With regard to the definition of intrapreneurship which comprised a dual etymology (CE and EEA) this study focuses on the the EEA as a subset of ID; nevertheless accepting the other subsets but not pursuing them while collecting data and running empirical tests.

At present time, entrepreneurship inside the organizations is a topic addressed in a multidisciplinary fashion (Stanworth, 1989; Hisrich, 1990; Carrier, 1994; Pearce et al.,1997; Allali, 2010; Alpkan, 2010; Bager et al, 2010; Bosma et al., 2010) while new perspectives, concepts and developments are emerging and interconnecting. Binding, social and corporate entrepreneurship, appears the "social intrapreneurship" concept (Grayson et al., 2011) as the creation of sustainable value (social and environmental innovations), for the benefit of the company itself and the society. Complementarily, the vision of social-orientated firms, creating pioneer solutions for social problems, arise with Venn and Berg (2013). It should not be overlooked a previous Kanter's (2010) contribution, underpinning business resilience lies on a sustainable organizational model (named as 
vanguardist model) with high business performance and social innovation impact without direct profit motivations (humanistic culture).

\subsection{The Intrapreneurship in Portugal}

The GEM Report review highlights the Nordic countries high perception of opportunity, and lower entrepreneurial abilities and Southern Europe lower business chances, contrasting higher indexes of entrepreneurial activity (Xavier et al., 2012). In the particular case of Portugal, the "nascent entrepreneurship rate" (new venturing) is lower than EU27 average, while the "discontinuation of businesses" figures are in line with EU other State-Members. Currently, the information available on the topic of intrapreneurship in Portugal is still scarce. The first study on the topic of intrapreneurship in Portugal was published in November 2012 by Dana T. Redford and it was called "INTRApreneurship in Portugal". This was a basic research study conducted by the Platform for Entrepreneurship Education in Portugal (PEEP), and the American Chamber of Commerce in Portugal (AMCHAM), and co-sponsored by the Luso-American Foundation (FLAD).

The next year, a country-comparison (Poland-Portugal) reviewed the original results on the field and was performed by Duarte et al. (2013) focusing on Micro, Small and Medium Enterprises (MSMEs). Focusing on the firms established at Vale do Sousa region in Portugal compared it with the Lublin province companies in Poland. These researchers concluded that the region of Vale do Sousa (composed by a business community with $97 \%$ of micro or small firms, and and $3 \%$ of medium enterprises) featured low intrapreneurship at the time. This study concluded that, just, 5,2\% of firms have good levels of intrapreneurship, 33,6\% a moderate level, and 61,2\% low, or very low, levels of intrapreneurship. Portuguese national figures compared with the Polish region under study, shown a weaker intrapreneurial performance at "moderate level", and "good level", and revealed an overall reduced ability to perform intrapreneurial dynamics in the Portuguese region.

A similar correlational study conducted about intrapreneurial cultures at Portuguese and Brazilian industrial companies (Lopes et al., 2013). The results revealed lower intrapreneurial behavior evidences in Portuguese firms, pointing as main obstacles, the centrality of decisions, the low autonomy of employees, the individual's alienation with business results, the lack of monitoring and evaluation (of intrapreneurial performance) and the lack of compensation and reward mechanisms.

\subsection{Organizational Conditions for the Entrepreneurship Development}

In the past, several studies have devoted attention to the correlation between the external environment and entrepreneurial performance and there is wide consensus on the influence of market factors on intrapreneurial behavior. Empirical evidences confirm many environmental variables are pushing companies towards the adoption of strategies of innovation and the assumption of risks (Behram and Özdemirci, 2014).

Paradoxically, some endogenous factors seem to be pulling down the intrapreneurial actions and innovation processes. Tidd et al. (2003) identified those factors as, the predominance of vertical relationships, weak lateral communication, limited resources and tools, top-down command orders, limitation on formal channels for change, valuing external innovation, and finally, unfocused activities and/or unplanned practices. The same authors also stress the importance of openness to new stimuli from the outside, and pull them into corporate thinking. Some researchers, hold that the internal firms' conditions play an important role enhancing intrapreneurial performance (Kuratko, Montagno and Hornsby, 1990; Carrier, 1994; Myzuka and Birley, 2001; Hashimoto, 2006; León et al., 2009; Allali (2010). and Lizete et al., 2013). 
First, Kuratko, Montagno and Hornsby (1990) considered the management support, the firm's structure and the availability of resources, the main internal constructs leading to entrepreneurial activity. While, Myzuka and Birley (2001) underpin the endogenous communication strategies, and Hashimoto (2006) stands internal communication is relevant for building an intrapreneurial culture. A broader vision, in line with Kuratko, Montagno and Hornsby (1990), is given by León et al. (2009). These authors state that the size of the firm, its structure, the rewards assigning and a managerial supportive team are internal requirements of entrepreneurship, whereas, Lizete et al. (2013) holds in a more linear manner, it comes from a combination of entrepreneurial competences and organizational factors.

Closer to Hashimoto (2006) are Behram and Özdemirci (2014) who claim the value of corporate culture in the ability to stand out as an entrepreneur. They distinguish between integrative and segmentalist cultures. Adhocracy and market cultures, taken as integrative yield a positive effect on intrapreneurial performance. The opposite way go the segmentalist cultures, which inhibit an entrepreneurial mindset. In the second case (segmentalist cultures), the authors add that the munificence associated with democratic management styles and leadership have negative effects on innovation and entrepreneurial activities.

\section{METHODOLOGY}

The research applies the Yin (2003) case design Type 2. The case research has an embedded format with multiple units of analysis (UAs) being observed, but focusing on a single-case design (one partaking firm) within the focal economic activity (insurance industry). The UAs constituted a sample of approximately $10 \%$ of the population within an universe of 670 employees of the firm. The sample was obtained through the response to an online questionnaire, applied at the intranet, monitored by the IT department with the approval of the strategic apex of the firm. The response rate of $9,70 \%$ constituted he final valid sample accounting stakeholders from different areas and locations at the central office and across local branches.

The questionnaire used closed-end enquiries related with the dimensions of Hartman's (2006) framework of intrapreneurial culture, which constituted the ground for measuring the perception of employees regarding IC. The responses to the questionnaire were linked to Likert scale of 5-points regarding the judgments of agreement and satisfaction. The dimensions of Hartman's framework constitute the independent variables for both, hypothesis testing and data estimation of IC/ID, based on the primary data collection.

The dependent variable shown below, as $\mathrm{Y}$ is associated with the Intrapreneurship Dynamics (ID) phenomenon whom is explained a combination of sub-variables that constitute the firm Intrapreneurship Conditions (IC). In turn the IC summarizes the set of independent variables, (X), as follows: (i) Vision and Objectives; (ii) Communication (VOC); (iii) Customer Focus (CuF); (iv) Strategy Communication (SCo); (v) Satisfaction on Incentives (QSI); (vi) Decision-Making viewing midterm results (DMR); (vii) Organizational Practices in accordance with communication policies (OrP); (viii) Ethical, Environmental and Social Responsibility Programs (SRP); (ix) Incentives for New Ideas (INI); (x) Incentives when a Entrepreneur Fails (IEF); and (xi) Stimuli of Ideas with no Obligation to Succeed (IOS). Figure 1 exhibits the research paradigm: 
Figure 1 Research paradigm (IC-ID)

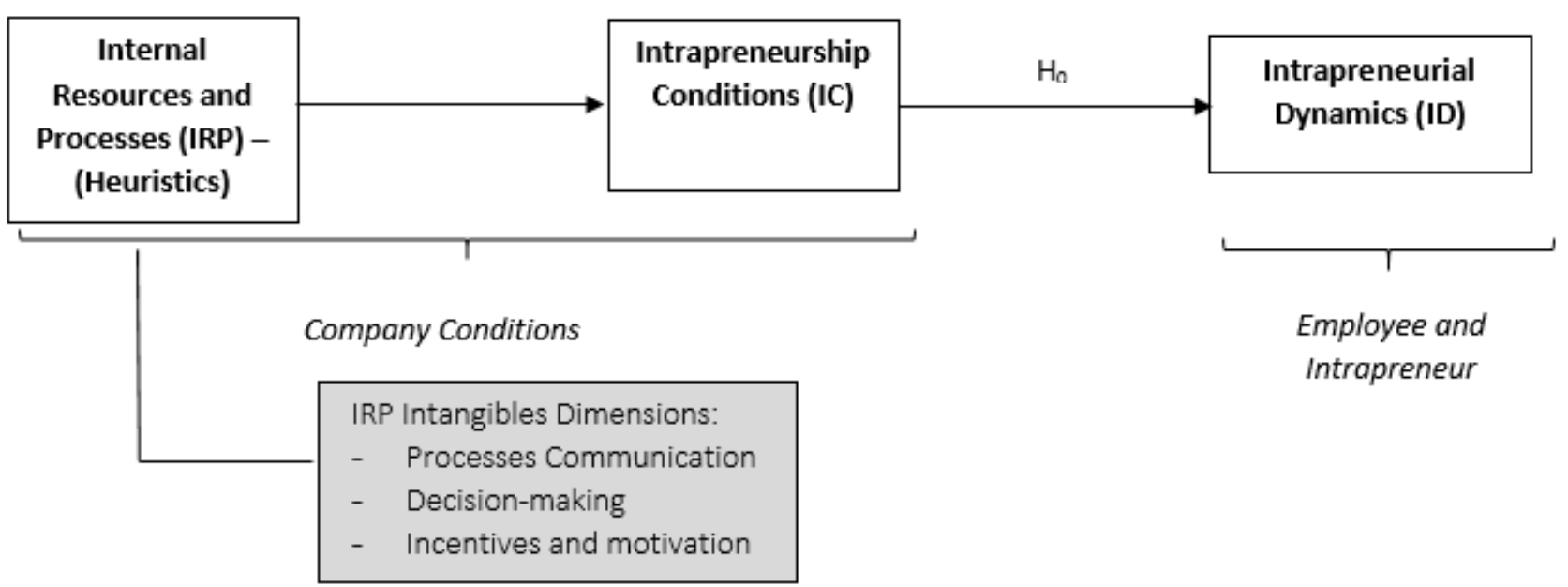

(Source: Own ellaboration)

The ontology of the case design reveal a foundation on the RBV as the RBT acknowledges that the capability formation is dependent on the existence of firms' resources and its utilization through the performance of groups of activities that obey a heuristic setting of perceived in the processes which be routinized. The bundle of resources and capabilities comprised in the firm's processes (IRP) and the firm's structure and environment set the tone for the intrapreneurial conditions described in Figure 2 that orientate the intrapreneurs actions.

This research basis itself on the resources and capabilities but focusing on the environmental conditions of the organizations, as an ID ecosystem for intrapreneurs that are the structuring aspects that trigger ID. Thus, the resources championed by the resources-based view (RBV) are deliberately untapped at our investigation. Based on the structural equation model for measuring ID we describe below the IC composition of sub-variables that account for the IC.

\section{Figure 2 IC conditionants of ID}

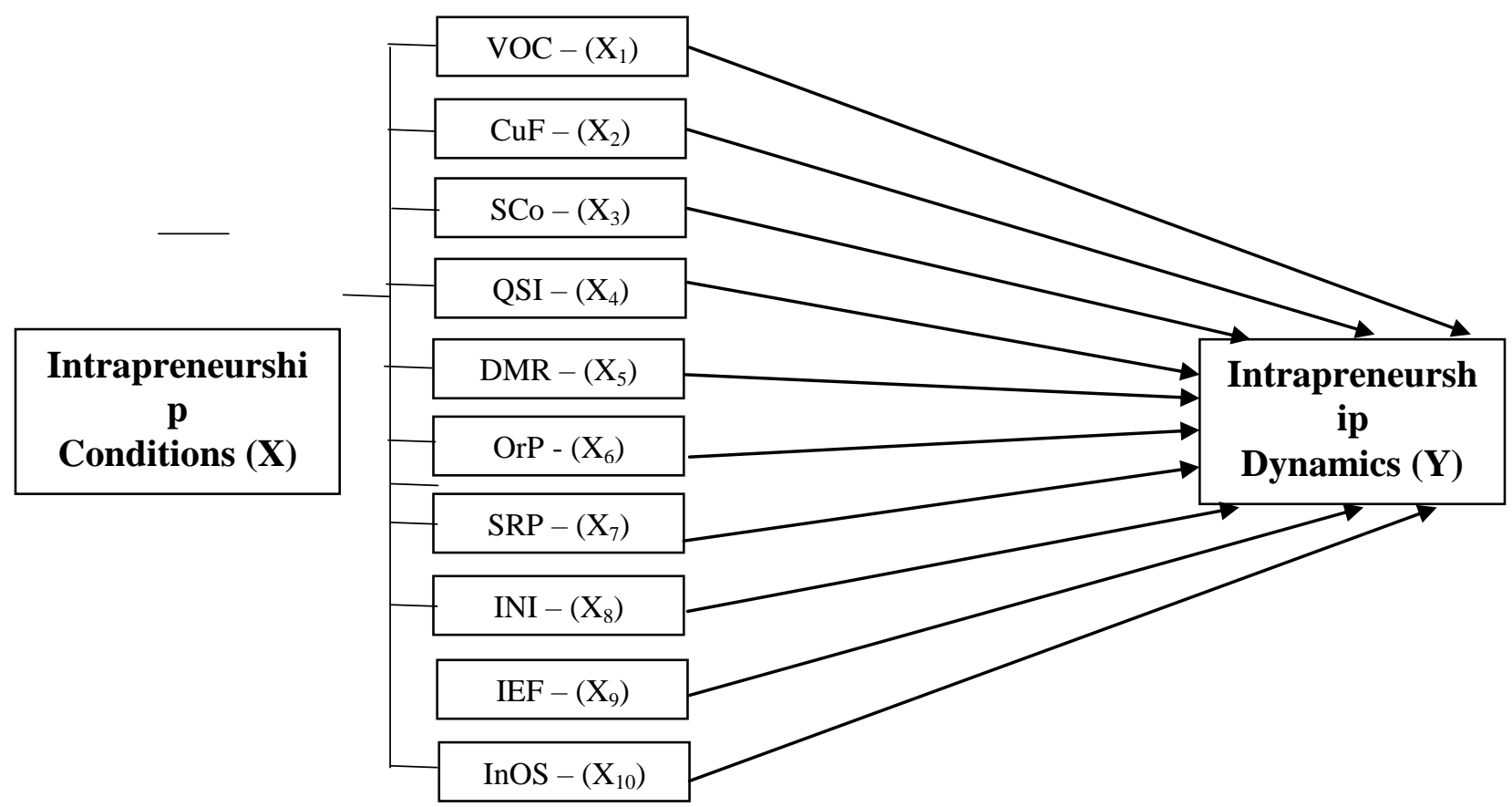

(Source: Own ellaboration) 
As referred, primary data follows Hartman's (2006) framework, applied in a questionnaire composed of 10 questions, each one related with an independent variable from $\mathrm{X}_{1}$ to $\mathrm{X}_{10}$. of Figure 2. The data analysis process incorporates descriptive and inferential statistical tools: frequencies, cross-tables, central tendency, dispersion measures, estimation and hypothesis testing. The estimating inference on population considers some assumptions for simple linear regressions. First, the linearity of relations between variables, then standard deviations of the error follows a normal distribution and finally, the variance is constant (homoscedastic). As null hypothesis (H0) is considered: the company provides the conditions for the development of intrapreneurial dynamics; and the alternative hypothesis (Ha) is a rejecting assertion of the $\mathrm{H} 0$ since is false. The significance level $(\alpha)$ is 0.05 with a confidence interval of 95 percent. The questionnaire design accounted in the question formulation phase a rhetorical assumption, which is the compromise to avoid polysemic and idiomatic language, which according to Hill and Hill (2012) hinders communication and can falsify the results of the questionnaires and therefore misrepresent the inference to the universe.

To assess the degree of agreement of the respondents to each of the survey questions of Hartman's questionnaire, was used a five elements (1-5) Likert Scale, with a bipolarity between strongly disagree and totally agree, respecting the properties of ordinal level (considering the transitivity principle) and intermediate level providing a constant magnitude throughout the scale. Our independent variables are linked with IRP dimensions through this connection: $\mathrm{X}_{1}$ to $\mathrm{X}_{4}$ variables answers the IP dimension of firm's communication, the $\mathrm{X}_{5}$ to $\mathrm{X}_{7}$ explains decision-making and the $\mathrm{X}_{8}$ to $\mathrm{X}_{10}$ the incentives and motivation. The questionnaire became available on the company intranet platform with a prior notification alert via e-mail, sent to all company employees.

\subsection{Case Study}

It was selected the insurance as an industry-target for its significance in the national macroeconomic context of the Portuguese economy. The case study was developed at one of the largest insurance companies in the world, with a relevant market share at Portugal and a large working population of six hundred and seventy employees, spread across all provinces (including the Azores and Madeira islands). The study was coordinated by the Communication and Brand Department of the company, with the technical support from the IT Department. The data collection features the following respondents profile: female worker, at Lisbon area (NUTS II - region 17) at the Great Lisbon area (NUTS III - region 171) at the age group of 35 to 44 years old, with a full-time job in the company, fulfilling non-operational functions at the subsidiary central office. Given the sample size $(n>30)$ it was applied a Kolmogorov-Smirnov's normality test to determine the normal distribution of the responses. Also confirmed were the skewness and kurtosis coefficients containing, respectively, symmetric figures (1.92) and a mesokurtic profile (0.844). We've also conducted an internal consistency analysis test to our primary data through Cronbach's alpha $(\alpha)$ to determine the reliability of the sample. The average interitem covariance got a 0.363 result and the scale reliability coefficient a 0.939 , proving its soundness. To determine the results of the survey, we've analyzed the responses using measures of central tendency, and dispersion.

Table 1 Results of central tendency

\begin{tabular}{lcr}
\hline Variables & Mean & Standard deviation \\
VOC - Vision Objectives \& Communication & 3.984 & $4.07 \mathrm{e}+08$ \\
$\mathrm{CuF}-$ Customer Focus & 4.046 & 1.038212 \\
$\mathrm{SCo}-$ Strategy Communication & 3.738 & .9590159 \\
\hline
\end{tabular}


QSI - Query Satisfaction on Incentives

DMR - Decision-making viewing midterm results

OrP - Organizational practice in accordance with communication policies

SRP - Ethical, environmental and social

responsibility programs

INI - Incentives for new ideas

$\mathrm{IEF}$ - Incentives when entrepreneurs failure

IOS - Stimulation of ideas with obligation to succeed

The results of the descriptive statistical summarized at Table 1 indicate: (a) an average of responses fitting grade 4 ("Agreement"), from question one to ten, except for question five, which presents an average rating of grade 3 ("Undecided "); (b) in question 7. There is a total agreement of the respondents; (c) its observed no responses with average ratings fitting grades 2 or 1 (disagreement or total disagreement). Noticeable is the dispersion measures ( $\mathrm{S}$ and $\mathrm{S}$-Squared) that show a high degree of variability in most of the answers. The aggregate results are exhibited in Table 2.

Table 2 Intrapreneurial condictions (IC) perception results

$\begin{array}{lrr}\text { Variables } & \text { Mean } & \text { Standard deviation } \\ \text { IC - Intrapreneurship Conditions } & 3.872 & 0.607\end{array}$

(Source: Own ellaboration)

The table below presents the correlation coefficient between the dependent variable (Y) the intrapreneurship dynamics (ID), and the independent variables $\left(\mathrm{X}_{1,2, \ldots \mathrm{n}}\right)$ measuring the strength of association between variables: vision and objectives communication (VOC); customer focus $(\mathrm{CuF})$; strategy communication (SCo); query satisfaction on incentives (QSI); decision-making viewing midterm results (DMR); Organizational practice in accordance with communication policies (OrP); ethical, environmental and social responsibility programs (SRP); Incentives for new ideas (INI); Incentives when entrepreneurs failure (IEF); Stimulation of ideas without obligation to succeed (IOS).

\section{Table 3 Results of Correlation Coeficient}

\section{Variables}

VOC - Vision Objectives \& Communication

$\mathrm{CuF}$ - Customer Focus

SCo - Strategy Communication

QSI - Query Satisfaction on Incentives

DMR - Decision-making viewing midterm results
Correlation Coeficient

0.7396

0.7044

0.7895

0.6344

0.7309 
OrP - Organizational practice in accordance with communication policies

SRP - Ethical, environmental and social responsability programs

INI - Incentives for new ideas

IEF - Incentives when entrepreneurs failure

IOS - Stimulation of ideas with obligation to succeed

(Source: Own ellaboration)

The Pearson's test results address the correlations $X_{1}-Y_{1}$ revealing considerable variability. The lowest figures values are linked with the environmental, ethical and social responsibility program (SRP). The maximum correlation values are achieved at "Organizational practice in accordance with communication and policies" (OrP). The correlation coefficient (r) of the medium variables $\mathrm{X}_{1}$ and $\mathrm{Y}_{1}$ according to the dependent variable was $\mathrm{r}=0.68933$. Furthermore, the variables of the operational model are presented below at the correlation matrix:

\section{Table 4 Results of Correlation Matrix}

\begin{tabular}{llllllllllll}
\hline Variables & ID & VCO & CuF & SCo & QSI & DMR & OrP & SRP & INI & IEF & IOS \\
\hline ID & 1.000 & & & & & & & & & & \\
\hline VCO & 0.739 & 1.000 & & & & & & & & \\
\hline CuF & 0.704 & 0.534 & 1.000 & & & & & & & \\
\hline SCo & 0.789 & 0.626 & 0.523 & 1.000 & & & & & & \\
\hline QSI & 0.634 & 0.385 & 0.496 & 0.417 & 1.000 & & & & & \\
\hline DMR & 0.730 & 0.592 & 0.416 & 0.598 & 0.311 & 1.000 & & & & \\
\hline OrP & 0.826 & 0.552 & 0.580 & 0.627 & 0.420 & 0.555 & 1.000 & & & \\
\hline SRP & 0.514 & 0.417 & 0.422 & 0.328 & 0.428 & 0.108 & 0.382 & 1.000 & & \\
\hline INI & 0.600 & 0.268 & 0.177 & 0.417 & 0.274 & 0.320 & 0.510 & 0.423 & 1.000 & & \\
\hline IEF & 0.632 & 0.326 & 0.368 & 0.408 & 0.316 & 0.410 & 0.485 & 0.202 & 0.316 & 1.000 & \\
\hline IOS & 0.720 & 0.320 & 0.342 & 0.462 & 0.445 & 0.511 & 0.557 & 0.215 & 0.524 & 0.545 & 1.00 \\
\hline & & & & & & & & & & &
\end{tabular}

(Source: Own ellaboration)

Based on the correlation results, we have applied the determination coefficient ( $\mathrm{r} 2)$, checking the variation degree of the intrapreneurship dynamics (IC) explained by independent variables (X) 1 to 10 .

\section{Table 5 Results of Determination Coeficient and Adjusted Corrrelation Coeficient}

Variables

\section{Determination Determination \\ coeficient coeficient}

(Adjusted)
VOC - Vision Objectives \& Communication
$\mathrm{CuF}$ - Customer Focus
0.547
0.539
0.496
0.488 
SCo - Strategy Communication

0.623

0.617

QSI - Query Satisfaction on Incentives

0.402

DMR - Decision-making viewing midterm results

0.534

OrP - Organizational practice in accordance with

0.683

0.678

communication policies

SRP - Ethical, environmental and social responsibility

0.264

0.253

programs

INI - Incentives for new ideas

0.360

0.350

IEF - Incentives when entrepreneurs failure

0.400

0,390

IOS - Stimulation of ideas with obligation to succeed

\section{(Source: Own ellaboration)}

The determination coefficient results register an $r^{2}$ (mean of $\left.X_{1-10}\right)=0.475$ and an $r^{2}$-adjusted $=$ 0.474 explaining the ID perception through the overall factors. OrP $\left(\mathrm{Y}_{6}\right)$ accounting an $\mathrm{r} 2$-adjusted $=0.678$, constitutes the most relevant explanatory factor $\left(\mathrm{X}_{1-10}\right)$ explaining ID perception according to the questionnaires responses. Therefore, the firm's management practices in compliance with its internal communication and polices was considered the factor which contributed the most for ID positive perception. On the other hand, SRP $\left(\mathrm{Y}_{7}\right)$ and INI $\left.{ }_{\mathrm{Y} 8}\right)$ were the major constraints to IC perception. Thus, "ethical, environmental and social responsibility programs" (SRP) and "Incentives for new ideas" (INI) were perceived the factors that contribute less to ID positive perception.

To review the degree of adjustment between variables $(\mathrm{x}, \mathrm{y})$ a regression was ran attaining the following results:

\section{Table 6 Results of the OLS Regression}

Variables

VOC - Vision Objectives \& Communication

$\mathrm{CuF}$ - Customer Focus

SCo - Strategy Communication

QSI - Query Satisfaction on Incentives

DMR - Decision-making viewing midterm results

OrP - Organizational practice in accordance with communication
Coef.

$0.433 * * *$

[0.496]

$0.446 * * *$

[0.566]

$0.575^{* * *}$

$[0.563]$

$0.470 * * *$

[0.722]

$0.434 * * *$

[0.510]

$0.546 * * *$ 
policies

SRP - Ethical, environmental and social responsibility programs

INI - Incentives for new ideas

$0.405^{* * *}$

[0.680]

IEF - Incentives when entrepreneurs failure

$0.475^{* * * *}$

[0.732]

IOS - Stimulation of ideas with obligation to succeed

$0.476 * * *$

$[0.578]$

$* \mathrm{p}<0.05, * * \mathrm{p}<0.01, * * * \mathrm{p}<0.001 ;$ standard errors in parentheses.

(Source: Own elaboration)

The regress model demonstrates the mean results (per variable $\mathrm{x}_{1-\mathrm{n}}$ ) of $\mathrm{t}$ statistics (from 0.433 to 0.682), a noteworthy standard error, graphically demonstrated below (from 0.143 at SRP to 0.732 at IEF) and some minor differences between $X_{1}$ to $X_{10}$ at the confidence interval considering ID as the dependent variable (Y). The SRP program usually a milestone on social programs its graph reveals the respondent's positive perception (Figure 2). In parallel, looking to the IC overall results it can identified the standard error and the heteroscedastic behavior of the sample (Figures 2 and 3).

Figure 2 SRC Results

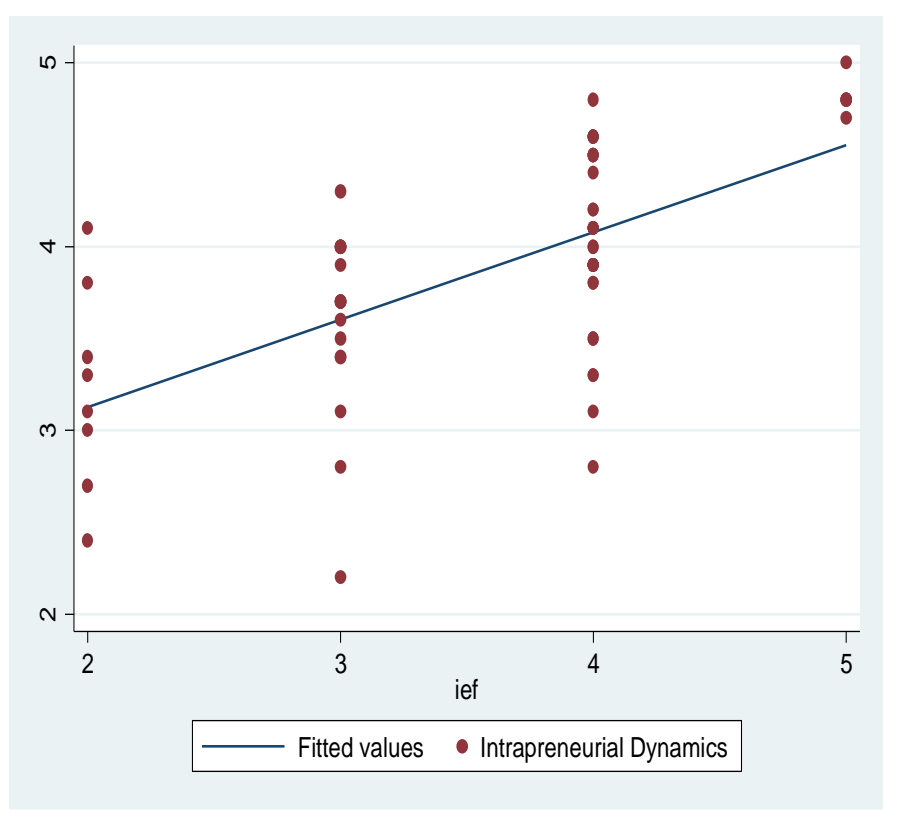

(Source: Own elaboration) 


\section{Figure 3 SRP results, standard error (U) and heteroscedasticity}

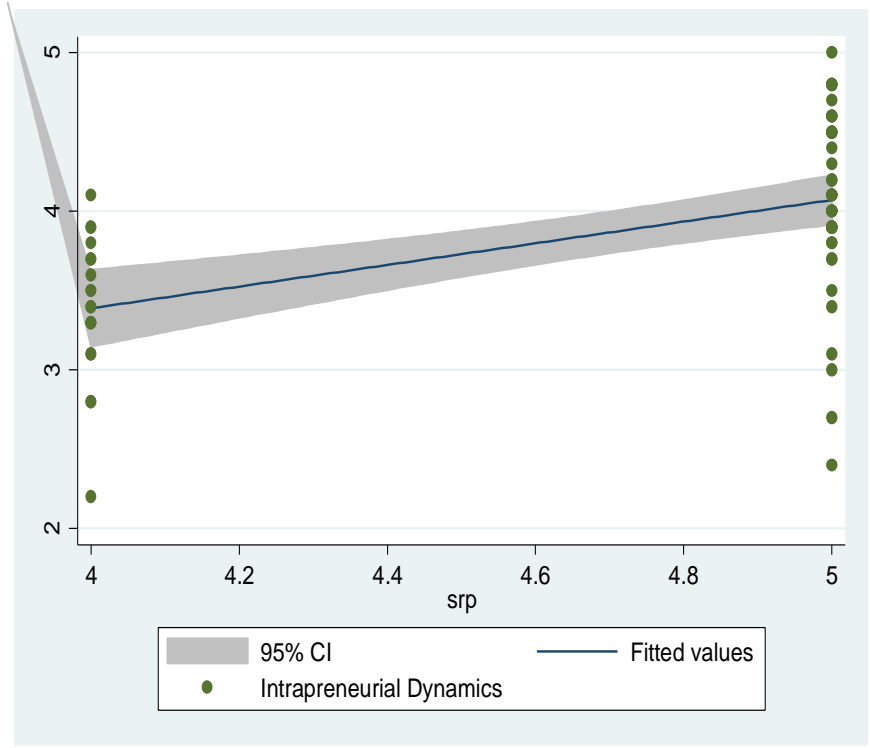

(Source: Own elaboration)

The responses demonstrate a considerable uncertainty and quite distinct outcomes per each dimension (or independent variable). The overall results lead to a $p$-value below 0.05 ( $p<0.05)$. The overall perception of the respondents about ID considering data collected from the questionnaires and regarding the IC explanatory factors/dimensions $(\mathrm{X})$ or independent variables withdrawn from Hartman's (2006) study leads to the deductive observation that IC impacts directly on ID. Therefore, it may be claimed that the intrapreneurial behaviors are intrinsically linked with the perception of the organizational environment and most specifically related with the existence of favorable ecosystems. ID is influenced by multiple criteria of the IC phenomenon and the latter exhibiting interdependencies in their variation.

\section{DISCUSSION AND CONCLUSION}

The empirical study is comprised in a research paradigm following a positivistic philosophical stance, with a deductive approach to theory development, where its design applies to quantitative approach a case research strategy of type 2 (Yin, 2009). The results of the study indicate a clear correlation between the intentions of the employees in the organization to engage in intrapreneurial dynamics in a EEA perspective, according to the corporate culture, organizational environments structure and resources. The results reveal that organizational environment influence the intentions of the employees to engage in intrapreneurial actions inside the organization. Moreover, it is recognized the existence of intangible endogenous processes that influence decisively the entrepreneurial practices. The most significant is OrP (Organizational practices in accordance with communication policies) which has the highest impact factor on employees positive perception of conditions for ID. On the other hand, SRP (Ethical, Environmental and Social Responsibility Programs) and INI (Incentives for New Ideas), had the lowest impact factors in employees perception. In this sense, the pecuniary intrinsic factors seem to don't account much for motivate potential intrapreneurs. Nevertheless, intrapreneurs reveal aversion to uncertainty as the OrP is the variable hampering their actions the most, which contradicts some of the myths in literature regarding the risk-acceptance of the entrepreneurs. Moreover, the recognition of the uncertainty avoidance by EEA candidates raises the quest for the structural flexibility of the organizations to 
match their business strategies with corporate policies accommodating intrapreneurship-friendly ecosystems and levering further innovations.

\section{REFERENCES}

Allali, B. (2010) Intrapreneuriality and the perceived autonomy indicators. International Journal of Entrepreneurship and Small Business, 10, no.:3, pp. 324-338.

Alpkan, L., Bulut, C., Gunday, G., Ulusoy, G., \& Kilic, K. (2010) Organizational support for intrapreneurship and its interaction with human capital to enhance innovative performance. Management decision, 48, no.:5, pp. 732-755.

Antoncic, B, Hirsch, R. D. (2001) Intrapreneurship: Construct, Refinement and Cross-Cultural Validation. Journal of Business Venturing, 16, no.:5, pp. 495-527.

Audrescht, D. B., Thurik, R., \& Verheul, I., Wennekers, S. (2002) Entrepreneurship: Determinants and Policy in a European-U.S. Comparison. Kluwer Academic Publishers.

Bager, T., Ottosson, H., \& Schott, T. (2010) Intrapreneurs, entrepreneurs and spin-off entrepreneurs: similarities and differences. International Journal of Entrepreneurship and Small Business, 10, no.:3, pp. 339-358.

Baruah, B. \& Ward, A. (2013). Can CEOs Be Influential Facilitators of Intrapreneurship. Voice of Research, 2, no.:3, pp. 47-54.

Behram, N. K., \& Özdemirci, A. (2014) The Empirical Link between Environmental Conditions, Organizational Culture, Corporate Entrepreneurship and Performance: The Mediating Role of Corporate Entrepreneurship. International Journal of Business and Social Science, 5, no.:2, pp. 264-276.

Bosma, N., Stam, E., \& Wennekers, S. (2013) Institutions and the allocation of entrepreneurship across new and established organizations (No. H201213). EIM Business and Policy Research.

Brandão, N. G. (2008) Século XXI - Novas solidariedades e incertezas. Lisboa, Edições Universitárias Lusófonas.

Brennan, L. \& Garvey, D. (2009) The role of knowledge in internationalization, Research in International Business and Finance, 23, no.:2, pp. 120-133.

Cardeal, N., \& Nelson, A. (2012) Valuable, rare, inimitable resources and organization (VRIO) resources or valuable, rare, inimitable resources (VRI) capabilities: What leads to competitive advantage?. African Journal of Business Management, 6, no.:37, pp. 10159-10170.

Carrier, C. (1994) Intrepreneurship in large firms and SMEs: A comparative study. International Small Business Journal, 12, no.:3, pp. 54-61.

Duarte, N., Diniz, F., Arent, A. \& Bojar, M. (2013) Entrepreneurship Strategies in a Portuguese and in a Polish Region. Proceedings of the first international conference on management, marketing tourism, retail, finance, and computer aplications, Croatia.

Eisenhardt, K. M., \& Martin, J. A. (2000) Dynamic capabilities: what are they?. Strategic management journal, 21, no.:10-11, pp. 1105-1121.

Freixo, M. (2012) Metodologia Cientifica - Fundamentos, Métodos e Técnicas, $4^{\mathrm{a}}$ ed., Instituto Piaget, Lisboa.

Grayson, D., MClaren, M, \& Spitzeck, H. (2011) Social Intrapreneurs-An Extra Force for Sustainability, A Doughty Centre for Corporate Responsibility Occasional Paper.

Hartman, A. (2006) Avaliação da Cultura Intra-Empreendedora: Desenvolvimento e Teste de uma Metodologia, Ponta Grossa-PR: Universidade Tecnológica Federal do Paraná.

Hashimoto, M. (2006) Espírito Empreendedor nas organizações:aumentando a competitividade através do intraemprendedorismo. Saraiva.

HILL,M. M. \& HILL, A. (2012) Investigação por Questionário (2a ed.). Lisboa, Edições Sílabo.

Kanter, R. K. (2010) Superempresa. Lisboa, Actual Editora.

KAO, John J. (1989) Entrepreneurship, Creativity \& Organization, Prentice-Hall. 
Kelley, D. J., Singer, S., \& Herrington, M. (2012) The global entrepreneurship monitor. 2011 Global Report, GEM 2011, 7.

KOVÁCS, Ilona (1993) Sistemas Antropocêntricos de Produção, Lisboa, SOCIUS - Centro de Investigação em Sociologia Económica e das Organizações, Lisboa.

Kovács, I., Castillo, J. J., \& Pereira, M. S. (1998) Novos modelos de produção: trabalho e pessoas. Celta Editora, Oeiras.

Kuratko, D. F., Montagno, R. V., \& Hornsby, J. S. (1990) Developing an intrapreneurial assessment instrument for an effective corporate entrepreneurial environment. Strategic Management Journal, 11, no.:1, pp. 49-58.

Kuratko, D. F., \& Hodgetts, R. M. (1995) Entrepreneurship: A contemporary approach. Dryden Press.

Grayson, D., McLaren, M., \& Spitzeck, H. (2011) Social Intrapreneurs-An Extra Force for Sustainability. A Doughty Centre for Corporate Responsibility Occasional Paper.

Hisrich, R. D. (1990). Entrepreneurship/intrapreneurship. American Psychologist, 45, no.:2, p. 209.

León, J. A. M., Topa, G., Valero, E., \& Lévy, J. P. (2009) Identificación organizacional y conducta" intraemprendedora". Anales de psicología, 25, no.:2, pp. 277-287.

Lizote, S. A., Verdinelli, M. A., \& Silveira, A. (2013) Organizational Factors and Intrapreneurial Competences. International Journal of Innovation, 1, no.:1, pp. 01-18.

Lopes, S., Gaspar, F., Hartman, A., Silva, F., Reis, D. (2013) Avaliação do nível da cultura intraempreendedora: Estudo de caso entre seis empresas portuguesas e seis empresas brasileiras. Revista Portuguesa e Brasileira de Gestão, 12, no.:1, pp. 52-68.

Lozinsky, S. (2010) Implementando o empreendedorismo na sua empresa - Experiências e Idéias para Criar uma Organização (Intrapreneurship). São Paulo, M. Books.

Miller, D. (1983) The correlates of entrepreneurship in three types of firms. Management science, 29, no.:7, pp. 770-791.

Mintzberg, H. (2007) Mintzberg on Management. Simon \& Schuster.

Muzyka, D. F., \& Birley, S. (2001) Dominando os desafios do empreendedor. São. Paulo, Financial Times. Makron Books.

Oviatt, B. M., \& McDougall, P. P. (1994) Toward a theory of international new ventures, Journal of International Business Studies, 25, no.:1, pp. 45-64.

Pearce, J. A., Kramer, T. R., \& Robbins, D. K. (1997). Effects of managers' entrepreneurial behavior on subordinates. Journal of Business Venturing, 12, no.:2, pp. 147-160.

Pelmann, R. \& Pinchot, G. (1999). Intrapreneuring in Action: A Handbook for Business Innovation. San Francisco, Berrett-Koehler.

Pinchot III, G. (1985). Intrapreneuring: Why you don't have to leave the corporation to become an entrepreneur. University of Illinois at Urbana-Champaign's Academy for Entrepreneurial Leadership Historical Research Reference in Entrepreneurship.

Stanworth, J., Stanworth, C., Granger, B., \& Blyth, S. (1989) Who becomes an entrepreneur?. International Small Business Journal, 8, no. 1, pp. 11-22.

Teece, D. J., Pisano, G., \& Shuen, A. (1997) Dynamic capabilities and strategic management. Strategic Management Journal. 16, no.:7, pp. 509-533.

Tidd, J.; Pavitt, K. \& Bessant, J. (2003) Gestão da Inovação - Integração das mudanças tecnológicas, de trabalho e organizacionais. Lisboa, Monitor.

Tidd, J.; Pavitt, K. \& Bessant, J. (2009) Inovação e Empreendedorismo. Lisboa, Bookman.

Venn, R., \& Berg, N. (2013) Building competitive advantage through social intrapreneurship. South Asian Journal of Global Business Research, 2, no.:1, pp. 104-127.

Xavier, S. R., Kelley, D., Kew. J., Herrigton, M \& Vorderwülbecke, A. (2012) The GEM 2012 Global Report. Kuala Lumpur, GEM 2012.

Wang, C. L., \& Ahmed, P. K. (2007). Dynamic capabilities: A review and research agenda. International Journal of Management Reviews. 9, no.:1, 31-51. 
Weerawardena, J., Mort, G. S., Liesch, P. W., \& Knight, G. (2007). Conceptualizing accelerated internationalization in the born global firm: A dynamic capabilities perspective. Journal of World Business, 42, no.3, 294-306.

Yin, R. K. (2009). How to do better case studies. The SAGE handbook of applied social research methods.

Zahra, S. A. (1995). Corporate entrepreneurship and financial performance: the case of management leveraged buyouts. Journal of Business Venturing, 10, no.:3, pp. 225-247. 